\title{
Hahella chejuensis gen. nov., sp. nov., an extracellular-polysaccharide-producing marine bacterium
}

\author{
Hong Kum Lee, ${ }^{1}$ Jongsik Chun, ${ }^{2}$ Eun Young Moon, ${ }^{2}$ Sung-Hwan Ko, ${ }^{1}$ \\ Deuk-Soo Lee, ${ }^{1}$ Hyun Sang Lee ${ }^{1}$ and Kyung Sook Bae ${ }^{2}$
}

1 Microbiology Laboratory,
Korea Ocean R \& D
Institute, Ansan PO Box 29,
Seoul 425-600, Republic of
Korea
2 Korean Collection for Type
Cultures, Korea Research
Institute of Bioscience and
Biotechnology, PO Box
115, Yusong, Taejon
305-600, Republic of Korea

\section{INTRODUCTION}

Microbial extracellular polysaccharides (EPSs) have been used in a wide variety of industrial applications such as emulsification, gel formation, absorption, film formation and anticancer treatment $(\mathrm{Fu} \& \mathrm{Tseng}$, 1990; Irene et al., 1990; Martins et al., 1990; Low et al., 1998). They have been found in various microorganisms including Alteromonas, Cyanothece, Pseudomonas, Vibrio and Zoogloea (Ikeda et al., 1982; Rodrigues \& Bhosle, 1991; Matsuda \& Worawattanamateekul, 1993; Philippis et al., 1993; Raguenes et al., 1996). Microbial EPSs have an advantage over polysaccharides from other sources, as they can be produced in large quantity using a relatively simple purification process. A bacterial strain producing a large amount of EPS was isolated from a marine sediment sample collected from Marado, Cheju

Abbreviation: EPS, extracellular polysaccharide.

The GenBank accession number for the 165 rDNA sequence of Hahella chejuensis KCTC $2396^{\top}$ is AF195410.
Island, Republic of Korea. Our preliminary study indicated that EPSs produced by the isolate are of high molecular mass (over $2 \times 10^{6} \mathrm{Da}$ ), consist of galactose, glucose, xylose and ribose, and have good potential as an emulsifying agent (Ko et al., 2000). In the present study, we report the polyphasic characterization of this isolate, and propose that it belongs to a novel species, which is named Hahella chejuensis gen. nov., sp. nov.

\section{METHODS}

Bacterial strains. A marine sediment sample was collected from Marado, Cheju Island, Republic of Korea, at a depth of $1 \mathrm{~m}$. The sample was diluted with saline $(0.85 \% \mathrm{NaCl})$, spread onto ZoBell's medium ( 5 g peptone, 1 g yeast extract, $0.01 \mathrm{~g} \mathrm{FePO}_{4}, 15 \mathrm{~g}$ agar, $250 \mathrm{ml}$ distilled water, $750 \mathrm{ml}$ aged seawater), and incubated at $20^{\circ} \mathrm{C}$. A bacterial strain, designated $96 \mathrm{CJ} 10356^{\mathrm{T}}$, was isolated and shown to produce a large quantity of EPS. The strain was maintained as a glycerol suspension $(20 \%, \mathrm{w} / \mathrm{v})$ at $-80^{\circ} \mathrm{C}$.

Morphology. The test strain was grown on basal medium (BM; $10 \mathrm{~g}$ tryptone, $20 \mathrm{~g}$ sucrose, $4 \mathrm{~g} \mathrm{MgSO}_{4}, 7 \mathrm{~g} \mathrm{CaCl}_{2}$, 
$0.07 \mathrm{~g} \mathrm{KH}_{2} \mathrm{PO}_{4}, 0.08 \mathrm{~g} \mathrm{~K}_{2} \mathrm{HPO}_{4}, 5 \mathrm{mg} \mathrm{FeCl}, 1 \mathrm{mg} \mathrm{MnCl}_{2}$, $1 \mathrm{mg} \mathrm{Na}{ }_{2} \mathrm{MoO}_{4}, 1 \mathrm{mg} \mathrm{ZnCl}, 10 \mathrm{~g} \mathrm{NaCl}, 11$ distilled water) for $3 \mathrm{~d}$ at $37^{\circ} \mathrm{C}$. Morphology was observed by a differential interference microscope (Nikon), and Phillips model SEM 515 scanning and CM 20 transmission electron microscopes. Negative staining was performed with an aqueous solution $(2 \%, \mathrm{w} / \mathrm{v})$ of phosphotungstic acid adjusted to $\mathrm{pH} 7$, as described previously (Robinson et al., 1987).

Phenotypic tests. The basal medium (BM), incubated at $37^{\circ} \mathrm{C}$, was used for phenotypic tests, unless otherwise stated The motility of young cells was examined using wet mounts. Growth under anaerobic conditions was determined by testing the growth of the strain on BM agar at $30{ }^{\circ} \mathrm{C}$ in an anaerobic chamber $\left(5 \% \mathrm{CO}_{2}, 7 \% \mathrm{H}_{2}, 88 \% \mathrm{~N}_{2}\right.$; Forma Scientific). Catalase production was assayed by using $0 \cdot 3 \%$ hydrogen peroxide with a colony taken from BM agar plates. Oxidase activity was determined by the method of Kovacs (1956). The growth temperature was tested over the range of $5-50{ }^{\circ} \mathrm{C}$ using $\mathrm{BM}$ broth. The requirement of $\mathrm{NaCl}$ for growth was tested using YMG broth (10 g glucose, $5 \mathrm{~g}$ peptone, $3 \mathrm{~g}$ yeast extract, $3 \mathrm{~g}$ malt extract, 11 distilled water) supplemented with concentrations of $\mathrm{NaCl}$ in the range of $0-20 \%$. The $\mathrm{pH}$ range for growth was determined using $\mathrm{BM}$ broth adjusted to different $\mathrm{pH}$ values over the range of 3-11.

Biochemical tests were done using API 20E and 20NE strips (bioMérieux) following the manufacturer's instructions. Utilization of carbohydrates as sole carbon source was examined using modified $\mathrm{BM}$ that was prepared by replacing tryptone with $0.5 \%(\mathrm{w} / \mathrm{v}) \mathrm{NH}_{4} \mathrm{Cl}$, and sucrose with $1 \%$ $(\mathrm{w} / \mathrm{v})$ carbohydrates. For acid production tests, bromothymol blue was added to a final concentration of $0.05 \mathrm{~g} \mathrm{l}^{-1}$.

Pigment. Strain 96CJ10356 ${ }^{\mathrm{T}}$ was grown in $100 \mathrm{ml} \mathrm{BM}$ broth at $30^{\circ} \mathrm{C}$ for $7 \mathrm{~d}$. Biomass was removed by centrifugation at $10000 \mathrm{~g}$ for $20 \mathrm{~min}$, following the addition of $0.1 \mathrm{~g} \mathrm{di}$ atomaceous earth (Sigma). The pigments were extracted from the supernatant using 2 vols methanol and chloroform, and analysed using a scanning UV/Visible spectrophotometer (Pharmacia Ultrospec 2000).

Cellular fatty acid analysis. Fatty acid methyl esters were prepared from biomass that was scraped from marine TSA [Tryptic Soy Agar (Difco), 50\% aged seawater] incubated at $30^{\circ} \mathrm{C}$ for $3 \mathrm{~d}$. Cellular fatty acids of the test strain were analysed as methyl esters by GC according to the instructions of the Microbial Identification System (MIDI).

Determination of DNA base composition. DNA was prepared according to Chun \& Goodfellow (1995). The mol \% G +C content of the resultant DNA preparations was determined using the thermal denaturation method (Mandel \& Marmur, 1968).

16S rDNA analysis. The primary structure of $16 \mathrm{~S}$ rDNA was determined as described earlier (Chun \& Goodfellow, 1995). The resultant sequence of strain $96 \mathrm{CJ} 10356^{\mathrm{T}}$ was manually aligned with representative sequences of the $\gamma$ Proteobacteria obtained from the Ribosomal Database Project (Maidak et al., 1997) and GenBank databases, using known 16S rRNA secondary structure information (Gutell, 1994). Phylogenetic trees were inferred by using the Fitch-Margoliash (Fitch \& Margoliash, 1967) and neighbour-joining (Saitou \& Nei, 1987) methods. Evolutionary distance matrices for the neighbour-joining and Fitch-Margoliash methods were generated according to the model of Jukes \& Cantor (1969). The trees were rooted using Rhizobium leguminosarum (GenBank accession no. D14513) as an outgroup. The
PHYLIP package (Felsenstein, 1993) was used for all analyses. The resultant neighbour-joining tree topology was evaluated by bootstrap analyses (Felsenstein, 1985) based on 1000 resamplings.

Nucleotide sequence accession numbers. The GenBank accession numbers of the published 16S rDNA sequences used in this study are Y12579 (Alcanivorax borkumensis DSM 11573 ${ }^{\mathrm{T}}$ ), AF001375 (Colwellia psychroerythraea ATCC 27364 ${ }^{\mathrm{T}}$, X67023 (Halomonas elongata ATCC $33173^{\mathrm{T}}$ ), X67022 (Marinobacter hydrocarbonoclasticus ATCC 49840 ${ }^{\mathrm{T}}$ ), U58339 (Marinobacterium georgiense DSM $11526^{\mathrm{T}}$ ), AB006769 (Marinospirillum minutulum ATCC 19193 ${ }^{\mathrm{T}}$ ), U58338 (Microbulbifer hydrolyticus DSM 11525 $5^{\mathrm{T}}$ ), AF053734 (Neptunomonas naphthovorans NAG-2N-126 ${ }^{\mathrm{T}}$ ), M22365 (Oceanospirillum linum ATCC 11336 ${ }^{\mathrm{T}}$ ), X06684 (Pseudomonas aeruginosa DSM 50071 ${ }^{\mathrm{T}}$ ) and D14555 (Zymobacter palmae IAM $\left.14233^{\mathrm{T}}\right)$. The sequence of Marinomonas communis is in RDP as Mrm. commu2.

\section{RESULTS AND DISCUSSION}

\section{Phenotypic and chemotaxonomic characterization}

The strain, isolated from marine sediment, was Gramnegative, rod-shaped, and catalase- and oxidase-positive. It grew equally well under both aerobic and anaerobic conditions. The colony was visible after $2 \mathrm{~d}$ incubation on $\mathrm{BM}$ agar at $37^{\circ} \mathrm{C}$. The colour of colonies changed from pale orange to pinkish red, and
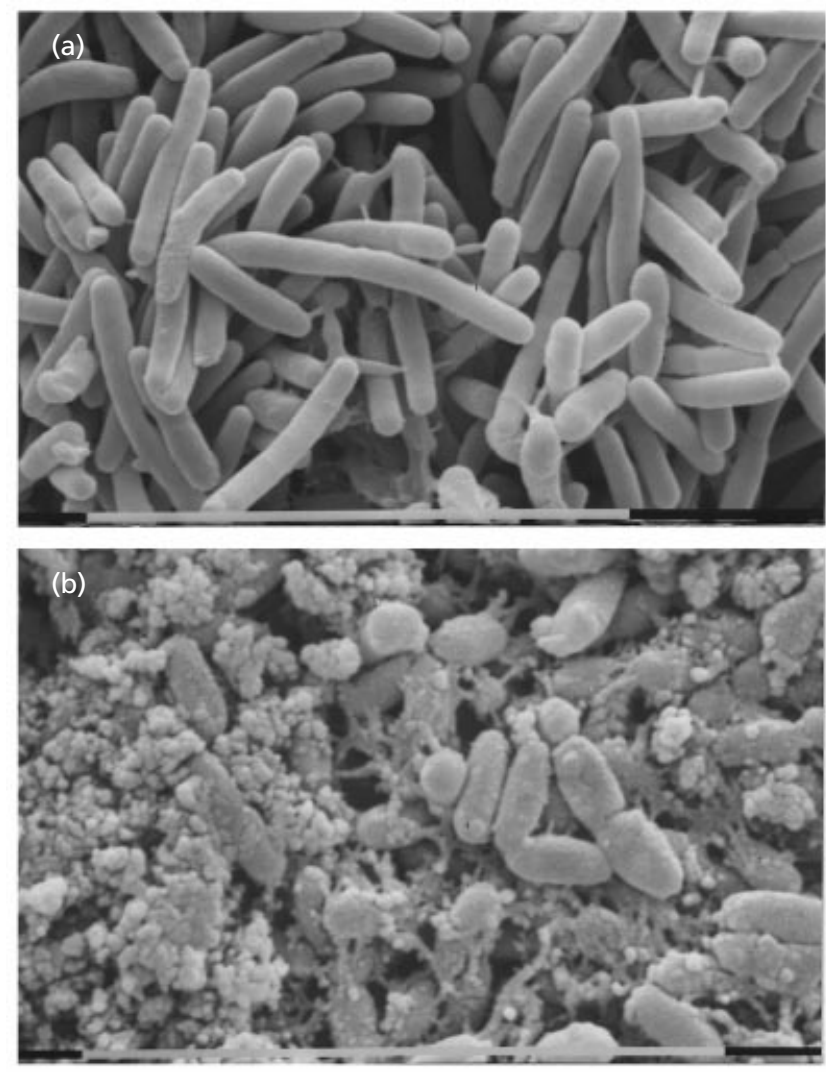

Fig. 1. Scanning electron micrographs of strain $96 \mathrm{CJ} 10356^{\top}$ : (a) young (1 d) and (b) old (7 d) cultures. Bar, $10 \mu \mathrm{m}$. 
Table 1 Phenotypic properties of isolate $96 \mathrm{CJ} 10356^{\top}$

ND, Not determined; v, variable reaction.

\begin{tabular}{|c|c|}
\hline Characteristic & Reaction of isolate \\
\hline \multicolumn{2}{|l|}{ Production of: } \\
\hline Acetoin & - \\
\hline $\mathrm{H}_{2} \mathrm{~S}$ & - \\
\hline Indole & - \\
\hline \multicolumn{2}{|l|}{ Enzyme activity } \\
\hline Arginine dihydrolase & - \\
\hline Cytochrome oxidase & + \\
\hline$\beta$-Galactosidase & - \\
\hline Lysine decarboxylase & - \\
\hline Nitrate reductase & + \\
\hline Ornithine decarboxylase & - \\
\hline Tryptophan deaminase & - \\
\hline \multicolumn{2}{|l|}{ Hydrolysis of: } \\
\hline Aesculin & + \\
\hline Gelatin & + \\
\hline Urea & - \\
\hline \multicolumn{2}{|l|}{$\begin{array}{l}\text { Utilization as sole carbon } \\
\text { source/acid production }\end{array}$} \\
\hline Adonitol & $+/+$ \\
\hline $\mathrm{L}(+)$ Arabinose & $-1-$ \\
\hline $\mathrm{D}(+)$ Cellobiose & $+/ \mathrm{ND}$ \\
\hline Citrate & $-/ \mathrm{ND}$ \\
\hline $\mathrm{D}(+)$ Fructose & $+/+$ \\
\hline $\mathrm{D}(+)$ Galactose & $-/-$ \\
\hline $\mathrm{D}(+)$ Glucose & $+/+$ \\
\hline Glycerol & $+/ \mathrm{ND}$ \\
\hline Inositol & $+/+$ \\
\hline $\mathrm{D}(+)$ Lactose & $-/-$ \\
\hline Malate & $-/ \mathrm{ND}$ \\
\hline Malonate & $-/ \mathrm{ND}$ \\
\hline $\mathrm{D}(+)$ Maltose & $+/+$ \\
\hline $\mathrm{D}(-)$ Mannitol & $+/+$ \\
\hline $\mathrm{D}(+)$ Mannose & $+/+$ \\
\hline $\mathrm{D}(+)$ Melibiose & $-/ \mathrm{ND}$ \\
\hline $\mathrm{D}(+)$ Raffinose & $-1-$ \\
\hline $\mathrm{L}(+)$ Rhamnose & $-1-$ \\
\hline $\mathrm{D}(-)$ Ribose & $-/ \mathrm{v}$ \\
\hline $\mathrm{D}(-)$ Sorbitol & $+/+$ \\
\hline Sucrose & $+/+$ \\
\hline $\mathrm{D}(+)$ Trehalose & $+/+$ \\
\hline $\mathrm{D}(+)$ Xylose & $-/ \mathrm{V}$ \\
\hline
\end{tabular}

the colonial shape from small circular to large volcanic form, after $3 \mathrm{~d}$. The cells were long rods in the young stage (1.6-9.0 $\mu \mathrm{m}$ long, $0.5-0.7 \mu \mathrm{m}$ wide; Fig. 1a), which later became short rods in stationary cultures (1.4-1.7 $\mu \mathrm{m}$ long, $0.7-0.8 \mu \mathrm{m}$ wide; Fig. 1b). The organism was motile by means of a single polar flagellum. Growth occurred between 20 and $45^{\circ} \mathrm{C}$. Extended incubation (up to 1 month) was required at 10 and $15^{\circ} \mathrm{C}$. The test strain grew in YMG broth with $1-8 \% \mathrm{NaCl}$, but not with $10 \%$, and at $\mathrm{pH} 6-10$, but not $\mathrm{pH}$ 5. Optimal growth was observed in BM broth
Table 2 Cellular fatty acid profile of isolate $96 \mathrm{CJ} 10356^{\top}$

\begin{tabular}{|lc|}
\hline Fatty acid & Composition (\%) \\
\hline Dodecanoic acid & $6 \cdot 3$ \\
3-Hydroxydodecanoic acid & $13 \cdot 3$ \\
Tetradecanoic acid & $6 \cdot 8$ \\
cis-9-Hexadecen-1-ol & $2 \cdot 3$ \\
1-Hexadecanol & $1 \cdot 3$ \\
cis-7-Hexadecenoic acid & $6 \cdot 6$ \\
cis-9-Hexadecenoic acid/iso-2- & $19 \cdot 4$ \\
hydroxypentadecanoic acid & $19 \cdot 1$ \\
Hexadecanoic acid & $24 \cdot 9$ \\
Octadecenoic acid & \\
\hline
\end{tabular}

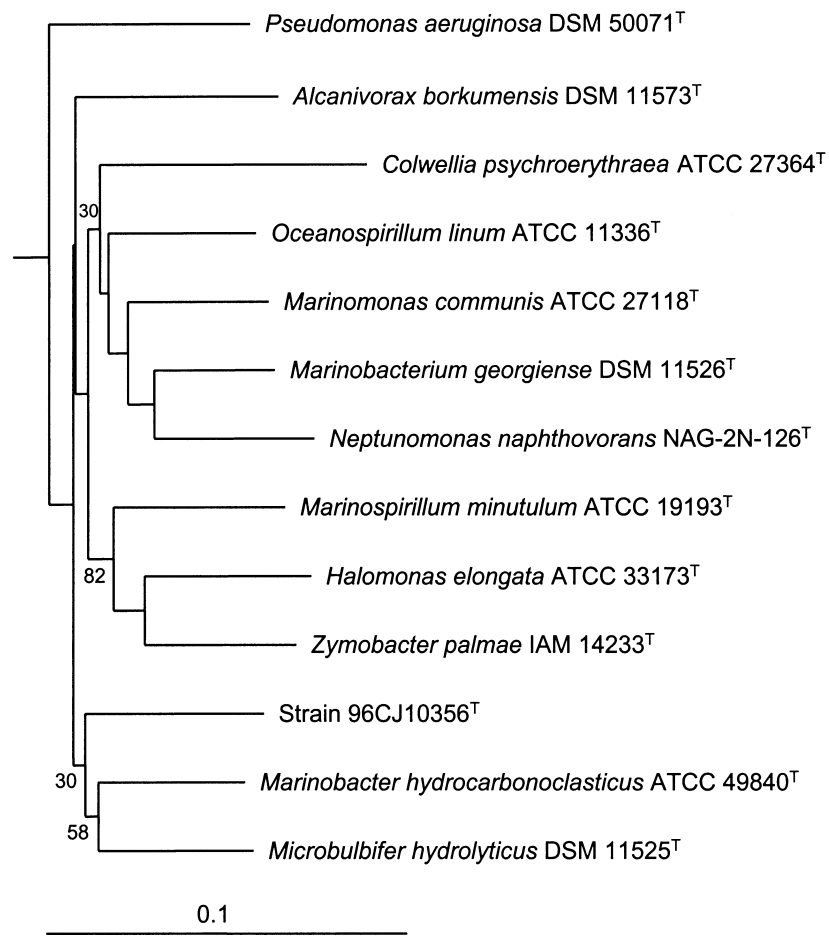

Fig. 2. Neighbour-joining tree based on almost complete $16 \mathrm{~S}$ rDNA sequences showing relationships between strain $96 \mathrm{CJ} 10356^{\top}$ and members of the $\gamma$ Proteobacteria. The percentage numbers at the nodes indicate the levels of bootstrap support for the branch point based on neighbourjoining analyses of 1000 resampled data sets. Rhizobium leguminosarum (accession no. D14513) was used as an outgroup. The scale bar indicates 10 nucleotide substitutions per 100 nucleotide positions.

with $2 \% \mathrm{NaCl}$ at $\mathrm{pH} 7$. The test organism was able to hydrolyse aesculin and gelatin. The results of biochemical and physiological tests are summarized in Table 1, and the profile of cellular fatty acids is given in Table 2. The pigment produced by strain 96CJ10356 ${ }^{\mathrm{T}}$ had maximum absorptions at 501.5 and $537 \mathrm{~nm}$, and was produced regardless of light. The $\mathrm{DNA} \mathrm{G}+\mathrm{C}$ ratio of the isolate was $55 \mathrm{~mol} \%$. 
Table 3 Phenotypic characteristics that differentiate strain $96 \mathrm{CJ} 10356^{\top}$ from other marine or halophilic bacteria belonging to the $\gamma$ subclass of the Proteobacteria

1, Strain 96CJ10356 ${ }^{\mathrm{T}} ; 2$, Alcanivorax borkumensis; 3, Halomonas elongata; 4, Marinobacter hydrocarbonoclasticus; 5 , Marinobacterium georgiense; 6, Marinomonas spp.; 7, Marinospirillum spp.; 8, Microbulbifer hydrolyticus; 9, Neptunomonas naphthovorans; 10, Oceanospirillum spp. Data from this and earlier studies (Gauthier et al., 1992; Gonzalez et al., 1997; Satomi et al., 1998; Hedlund et al., 1999). NR, Not reported; v, variable.

\begin{tabular}{|c|c|c|c|c|c|c|c|c|c|c|}
\hline & 1 & 2 & 3 & 4 & 5 & 6 & 7 & 8 & 9 & 10 \\
\hline Relation to oxygen & $\begin{array}{c}\text { Facultatively } \\
\text { anaerobic }\end{array}$ & $\begin{array}{c}\text { Facultatively } \\
\text { anaerobic }\end{array}$ & $\begin{array}{c}\text { Facultatively } \\
\text { anaerobic }\end{array}$ & $\begin{array}{c}\text { Facultatively } \\
\text { anaerobic }\end{array}$ & Aerobic & Aerobic & $\begin{array}{c}\text { Aerobic/ } \\
\text { microaerobic }\end{array}$ & Aerobic & $\begin{array}{c}\text { Facultatively } \\
\text { anaerobic }\end{array}$ & Aerobic \\
\hline Morphology & Rods & Rods & Rods & Rods & Rods & Rods & Spirilla & Rods & Rods & Spirilla \\
\hline Motility/flagella & $\begin{array}{c}+/ \text { Single } \\
\text { polar }\end{array}$ & $\begin{array}{c}+/ \text { Single } \\
\text { polar }\end{array}$ & $+/$ Peritrichous & $\begin{array}{c}+/ \text { Polar } \\
\text { OR - }\end{array}$ & $\begin{array}{c}+/ \text { Single } \\
\text { polar }\end{array}$ & $\begin{array}{c}+/ \text { Single } \\
\text { polar }\end{array}$ & $\begin{array}{c}+/ \text { Polar } \\
\text { tuft }\end{array}$ & - & $\begin{array}{c}+/ \text { Single } \\
\text { polar }\end{array}$ & $\begin{array}{c}+ \text { Bipolar } \\
\text { tufts }\end{array}$ \\
\hline Growth at $45^{\circ} \mathrm{C}$ & + & - & NR & + & - & + & - & - & - & - \\
\hline Oxidase & + & + & + & + & + & - & + & + & + & + \\
\hline Arginine dihydrolase & - & - & - & - & $\mathrm{NR}$ & - & NR & NR & NR & $\mathrm{NR}$ \\
\hline Citrate utilization & - & $\mathrm{NR}$ & $\mathrm{NR}$ & + & $\mathrm{NR}$ & NR & NR & NR & NR & NR \\
\hline Aesculin hydrolysis & + & - & $\mathrm{v}$ & NR & $\mathrm{NR}$ & $\mathrm{NR}$ & NR & $\mathrm{NR}$ & NR & - \\
\hline Gelatin hydrolysis & + & - & $\mathrm{v}$ & - & $\mathrm{NR}$ & $\mathrm{v}$ & NR & NR & - & - \\
\hline Lysine decarboxylase & - & - & + & - & $\mathrm{NR}$ & - & NR & NR & NR & NR \\
\hline Ornithine decarboxylase & - & - & + & - & NR & - & NR & NR & NR & NR \\
\hline Reduction of nitrate & + & + & + & + & - & - & $\mathrm{v}$ & - & - & - \\
\hline Urease & - & - & $\mathrm{v}$ & - & NR & - & NR & NR & NR & - \\
\hline $\mathrm{G}+\mathrm{C}$ content $(\mathrm{mol} \%)$ & 55 & $53-54$ & $60-61$ & 53 & 55 & $44-48$ & $43-45$ & 58 & 46 & $42-51$ \\
\hline
\end{tabular}

\section{Phylogenetic analysis}

An almost complete $16 \mathrm{~S}$ rDNA sequence of isolate 96CJ10356 ${ }^{\mathrm{T}}$ was determined (1422 bp). Preliminary sequence comparison against the $16 \mathrm{~S}$ rRNA sequences held in the GenBank and Ribosomal Database Project (Maidak et al., 1997) databases indicated that the organism belongs to the $\gamma$ subclass of the Proteobacteria. The sequence was manually aligned against representatives of the $\gamma$ Proteobacteria using the secondary structure model of bacterial 16S rRNA (Gutell, 1994). On the basis of 16S rDNA similarity, our isolate showed no apparent relationship with representative $\gamma$ Proteobacteria. The closest relatives are Oceanospirillum linum ATCC $11336^{\mathrm{T}}(89 \cdot 9 \% 16 \mathrm{~S}$ rDNA similarity), Microbulbifer hydrolyticus DSM $11525^{\mathrm{T}}(89.8 \%)$, Marinobacter hydrocarbonoclasticus ATCC $49840^{\mathrm{T}}(89 \cdot 6 \%)$, Pseudomonas mendocina LMG $1223^{\mathrm{T}}(89 \cdot 1 \%)$, Oceanospirillum multiglobuliferum IFO $13614^{\mathrm{T}}(89 \cdot 1 \%)$ and Halomonas salina ATCC $49509^{\mathrm{T}}(89.0 \%)$; none of the valid bacterial species showed more than $90 \%$ sequence homology values. Phylogenetic analysis was carried out using 1302 unambiguously aligned nucleotide positions. It is evident in the neighbour-joining tree shown in Fig. 2 that the isolate formed an independent phyletic line in the $\gamma$ Proteobacteria. The branching point of the isolate was not stable, as the corresponding bootstrap value was very low, i.e. $30 \%$. A very similar tree topology was reconstructed by the Fitch-Margoliash treeing algorithm (data not shown).

\section{Salt requirements}

Halophilic micro-organisms can be conveniently grouped according to their requirements for $\mathrm{NaCl}$ for growth (Larsen, 1986): slightly halophilic marine bacteria can grow in the presence of $2-3 \% \mathrm{NaCl}$; moderate halophiles grow over a much wider range of $\mathrm{NaCl}$ concentrations (5-20\%); extreme halophiles are able to grow in saturated $\mathrm{NaCl}$ and are usually unable to grow with $12 \%$ or lower $\mathrm{NaCl}$ concentration. Our isolate can be classified as slightly halophilic, since it was unable to grow in the absence of $\mathrm{NaCl}$ and grew optimally with $2 \% \mathrm{NaCl}$. In recent taxonomic investigations, a number of marine bacteria that belong to the $\gamma$ subclass of the Proteobacteria have been described. This group of bacteria was shown to be phylogenetically heterogeneous and physiologically diverse (Caumette et al., 1997; Satomi et al., 1998; TardyJacquenod et al., 1998; Yakimov et al., 1998; Bhupathiraju et al., 1999). The phylogenetic uniqueness of our isolate within the $\gamma$ Proteobacteria further expands the diversity of the halophilic bacteria. The organism also showed distinct phenotypic traits that are different from other halophilic members of the $\gamma$ Proteobacteria. The characteristics that differentiate isolate $96 \mathrm{CJ} 10356^{\mathrm{T}}$ from phylogenetically related marine or halophilic bacteria are summarized in Table 3. On the basis of phylogenetic and phenotypic evidence, we propose that isolate $96 \mathrm{CJ} 10356^{\mathrm{T}}$ be classified in the new genus Hahella as Hahella chejuensis gen. nov., sp. nov.

\section{Description of Hahella gen. nov.}

Hahella (Ha.hel'la. M.L. fem. n., named after Yung Chil Hah, a Korean bacteriologist who pioneered microbiological research in Korea).

Cells are Gram-negative, facultatively anaerobic, rodshaped and motile by means of a single polar flagellum. The organism uses several carbohydrates as carbon sources and produces acid from sugars. Nitrate is reduced to nitrite. The organism is unable to grow in the absence of $\mathrm{NaCl}$. Optimal growth at $2 \%(\mathrm{w} / \mathrm{v})$ $\mathrm{NaCl}$. Aesculin and gelatin are hydrolysed. Detailed 
properties are given in Tables 1 and 2. Extracellular polysaccharides are produced. Phylogenetically, the genus belongs to the $\gamma$ subclass of the Proteobacteria. The DNA G $+\mathrm{C}$ content of the type species is $55 \mathrm{~mol} \%$. The type and only species of the genus is Hahella chejuensis.

\section{Description of Hahella chejuensis sp. nov.}

Hahella chejuensis (che.ju.en'sis. M.L. adj. chejuensis pertaining to Cheju Island, Republic of Korea, geographical origin of the type strain of the species).

Gram-negative, halophilic, facultatively anaerobic rods. Colonies, incubated for $3 \mathrm{~d}$ on $\mathrm{BM}$ agar at $37^{\circ} \mathrm{C}$, are pinkish red and volcanic form. The cells are long rods in young cultures $(1.6-9 \cdot 0 \mu \mathrm{m}$ long, $0.5-0.7 \mu \mathrm{m}$ wide) and become short rods in stationary cultures (1.4-1.7 $\mu \mathrm{m}$ long, $0.7-0.8 \mu \mathrm{m}$ wide). Grows at 10 $45^{\circ} \mathrm{C}$, but not at $50{ }^{\circ} \mathrm{C}$, in the presence of $\mathrm{NaCl}$ $(1-8 \%)$ and at $\mathrm{pH} 6-10$. Grows optimally with $2 \%$ $\mathrm{NaCl}$ and at $\mathrm{pH}$ 7. Methanol-soluble red pigments, with maximum absorptions at 501.50 and $537.00 \mathrm{~nm}$, are produced. Phenotypic characteristics and the cellular fatty acid profile are given in Tables 1 and 2. The DNA G + C content of the type strain is $55 \mathrm{~mol} \%$. The type strain is $96 \mathrm{CJ} 10356^{\mathrm{T}}\left(=\mathrm{KCTC} 2396^{\mathrm{T}}=\right.$ IMSNU $11157^{\mathrm{T}}$ ).

\section{ACKNOWLEDGEMENTS}

We are grateful to Professor Hans Trüper for help with nomenclature. Part of this work was supported by the Biotech 2000 Program of the Ministry of Science and Technology, Korea.

\section{REFERENCES}

Bhupathiraju, V. K., McInerney, M. J., Woese, C. R. \& Tanner, R. S. (1999). Haloanaerobium kushneri sp. nov., an obligately halophilic, anaerobic bacterium from an oil brine. Int $J$ Syst Bacteriol 49, 953-960.

Caumette, P., Imhoff, J. F., Süling, J. \& Matheron, R. (1997). Chromatium glycolicum sp. nov., a moderately halophilic purple sulfur bacterium that uses glycolate as substrate. Arch Microbiol 167, 11-18.

Chun, J. \& Goodfellow, M. (1995). A phylogenetic analysis of the genus Nocardia with 16S rRNA gene sequences. Int $J$ Syst Bacteriol 45, 240-245.

Felsenstein, J. (1985). Confidence limits on phylogenies: an approach using the bootstrap. Evolution 39, 783-791.

Felsenstein, J. (1993). PHYLIP (phylogenetic inference package) version 3.5c. Seattle: University of Washington.

Fitch, W. M. \& Margoliash, E. (1967). Construction of phylogenetic trees. Science 155, 279-284.

Fu, J. F. \& Tseng, Y. H. (1990). Construction of lactose-utilizing Xanthomonas campestris and production of xanthan gum from whey. Appl Environ Microbiol 56, 919-923.

Gauthier, M. J., Lafay, B., Christen, R., Fernandez, L., Acquaviva, M., Bonin, P. \& Bertrand, J. C. (1992). Marinobacter hydrocarbonoclasticus gen. nov., sp. nov., a new, extremely halotolerant, hydrocarbon-degrading marine bacterium. Int $J$ Syst Bacteriol 42, 568-576.
Gonzalez, J. M., Mayer, F., Moran, M. A., Hodson, R. E. \& Whitman, W. B. (1997). Microbulbifer hydrolyticus gen. nov., sp. nov., and Marinobacterium georgiense gen. nov., sp. nov., two marine bacteria from a lignin-rich pulp mill waste enrichment community. Int J Syst Bacteriol 47, 369-376.

Gutell, R. R. (1994). Collection of small subunit (16S- and 16Slike) ribosomal RNA structures: 1994. Nucleic Acids Res 22, 3502-3507.

Hedlund, B. P., Geiselbrecht, A. D., Bair, T. J. \& Staley, J. T. (1999). Polycyclic aromatic hydrocarbon degradation by a new marine bacterium, Neptunomonas naphthovorans gen. nov., sp. nov. Appl Environ Microbiol 65, 251-259.

Ikeda, F., Shuto, H., Fukui, T. \& Tomita, K. (1982). An extracellular polysaccharide produced by Zoogloea ramigera 115 . Eur $J$ Biochem 123, 437-445.

Irene, B. M., Jansson, P. E. \& Lindberg, B. (1990). Structural studies of the capsular polysaccharide from Streptococcus pneumoniae type 7A. Carbohydr Res 198, 67-77.

Jukes, T. H. \& Cantor, C. R. (1969). Evolution of protein molecules. In Mammalian Protein Metabolism, pp. 21-132. Edited by H. N. Munro. New York: Academic Press.

Ko, S.-H., Lee, H.-S., Park, S. H. \& Lee, H. K. (2000). Optimal conditions for the production of exopolysaccharide by marine microorganism Hahella chejuensis. Biotechnol Bioprocess Eng $\mathbf{5}$, 181-185.

Kovacs, N. (1956). Identification of Pseudomonas pyocyanea by the oxidase reaction. Nature 178, 703.

Larsen, H. (1986). Halophilic and halotolerant microorganisms: an overview and historical perspective. FEMS Microbiol Rev 39, 3-7.

Low, D., Ahlgren, J. A., Horne, D., McMahon, D. J., Oberg, C. J. \& Broadbent, J. R. (1998). Role of Streptococcus thermophilus MR$1 \mathrm{C}$ capsular exopolysaccharide in cheese moisture retention. Appl Environ Microbiol 64, 2147-2151.

Maidak, B. L., Olsen, G. J., Larsen, N., Overbeek, R., McCaughey, M. J. \& Woese, C. R. (1997). The RDP (Ribosomal Database Project). Nucleic Acids Res 25, 109-111.

Mandel, M. \& Marmur, J. (1968). Use of ultraviolet absorbance temperature profile for determining the guanine plus cytosine content of DNA. Methods Enzymol 12B, 195-206.

Martins, L. O., Brito, L. C. \& Isabel, S. C. (1990). Roles of $\mathrm{Mn}^{2+}$ and $\mathrm{Ca}^{2+}$ on alginate biosynthesis by Pseudomonas aeruginosa. Enzyme Microb Technol 12, 794-799.

Matsuda, M. \& Worawattanamateekul, W. (1993). Structural analysis of a rhamnose-containing sulfated polysaccharide from a marine pseudomonas. Nippon Suisan Gakkaishi 59, 875-878.

Philippis, R., Margheri, M. C., Pelosi, E. \& Ventura, S. (1993). Exopolysaccharide production by a unicellular cyanobacterium isolated from a hypersaline habitat. J Appl Phycol 5, 387-394.

Raguenes, G., Pignet, P., Gauthier, G., Peres, A., Christen, R., Rougeaux, H., Barbier, G. \& Guezennec, J. (1996). Description of a new polymer-secreting bacterium from a deep-sea hydrothermal vent, Alteromonas macleodii subsp. fijiensis, and preliminary characterization of the polymer. Appl Environ Microbiol 62, 67-73.

Robinson, D. G., Ehlers, U., Herken, R., Herrmann, B., Mayer, F. \& Schürmann, F. W. (1987). Methods of Preparation for Electron Microscopy - an Introduction for the Biomedical Sciences. Berlin: Springer.

Rodrigues, C. \& Bhosle, N. B. (1991). Exopolysaccharide production by Vibrio fischeri, a fouling marine bacterium. Biofouling 4, 301-308. 
Saitou, N. \& Nei, M. (1987). The neighbor-joining method: a new method for reconstructing phylogenetic trees. Mol Biol Evol 4, 406-425.

Satomi, M., Kimura, B., Hayashi, M., Shouzen, Y., Okuzumi, M. \& Fujii, T. (1998). Marinospirillum gen. nov., with descriptions of Marinospirillum megaterium sp. nov., isolated from kusaya gravy, and transfer of Oceanospirillum minutulum to Marinospirillum minutulum comb. nov. Int $J$ Syst Bacteriol 48, 1341-1348.
Tardy-Jacquenod, C., Magot, M., Patel, B. K., Matheron, R. \& Caumette, P. (1998). Desulfotomaculum halophilum sp. nov., a halophilic sulfate-reducing bacterium isolated from oil production facilities. Int J Syst Bacteriol 48, 333-338.

Yakimov, M. M., Golyshin, P. N., Lang, S., Moore, E. R., Abraham, W. R., Lunsdorf, H. \& Timmis, K. N. (1998). Alcanivorax borkumensis gen. nov., sp. nov., a new, hydrocarbon-degrading and surfactant-producing marine bacterium. Int J Syst Bacteriol 48, 339-348. 